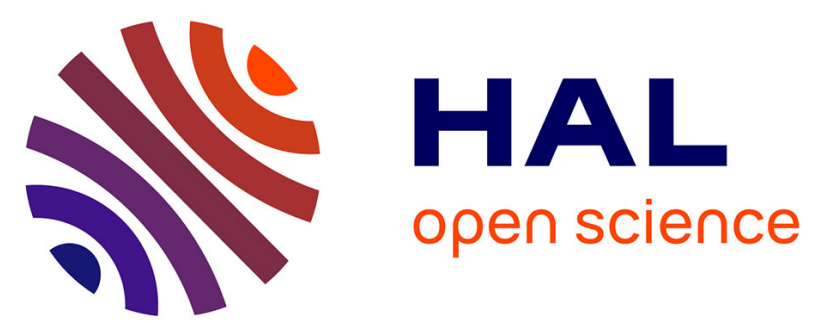

\title{
An investigation of links between metabolic rate and feed efficiency in European sea bass Dicentrarchus labrax
}

Charles Rodde, Hugues de Verdal, Marc Vandeputte, François Allal, Julie Nati, Mathieu Besson, Felipe Blasco, John Benzie, David J Mckenzie

\section{- To cite this version:}

Charles Rodde, Hugues de Verdal, Marc Vandeputte, François Allal, Julie Nati, et al.. An investigation of links between metabolic rate and feed efficiency in European sea bass Dicentrarchus labrax. Journal of Animal Science, 2021, 99 (6), pp.1-9. 10.1093/jas/skab152 . hal-03360566

\section{HAL Id: hal-03360566 \\ https: / hal.inrae.fr/hal-03360566}

Submitted on 22 Nov 2021

HAL is a multi-disciplinary open access archive for the deposit and dissemination of scientific research documents, whether they are published or not. The documents may come from teaching and research institutions in France or abroad, or from public or private research centers.
L'archive ouverte pluridisciplinaire HAL, est destinée au dépôt et à la diffusion de documents scientifiques de niveau recherche, publiés ou non, émanant des établissements d'enseignement et de recherche français ou étrangers, des laboratoires publics ou privés.

\section{(c)(1)}

Distributed under a Creative Commons Attribution| 4.0 International License 
1 Running head: Metabolic rate and feed efficiency in fish An investigation of links between metabolic rate and feed efficiency in European sea bass Dicentrarchus labrax ${ }^{1}$

Charles Rodde ${ }^{* \dagger}+\S^{2}$, Hugues de Verdal ${ }^{*} \dagger$, Marc Vandeputte $§$, François Allal $\S$, Julie

Nati§, Mathieu Besson§ | |, Felipe R. Blascoๆ, John A. H. Benzie $+\wedge$, David J. McKenzie§

*CIRAD, UMR ISEM, 34398 Montpellier, France.

$\dagger$ ISEM, Université de Montpellier, CNRS, EPHE, IRD, 34095 Montpellier, France

\$Worldfish, Jalan Batu Maung, Bayan Lepas, 11960, Penang, Malaysia

§MARBEC, Université de Montpellier, CNRS, Ifremer, IRD, 34250 Palavas-les-Flots, France

\#Université Paris-Saclay, INRAE, AgroParisTech, GABI, 78350 Jouy-en-Josas, France

I SSYSAAF Section Aquacole, Campus de Beaulieu, 35000 Rennes, France

ףLaboratório de Zoofisiologia e Bioquímica Comparativa, Departamento de Ciências

Fisiológicas, Universidade Federal de São Carlos, São Paulo, 13565-905, Brasil

K8AF, Ireland 
${ }^{1}$ This publication was made possible through support provided by CIRAD and the CGIAR Research Program on Fish Agrifood Systems (FISH) and the International Fund for Agricultural Development (IFAD). The authors are grateful to the Ifremer Experimental Aquaculture Research Station staff and facilities and to H2020 AQUAEXCEL2020 (No. 652831).

${ }^{2}$ Corresponding author: charlesrodde7@gmail.com

ABSTRACT: Feed efficiency (FE) is the amount of body weight gain for a given feed intake. Improving FE through selective breeding is key for sustainable finfish aquaculture but its evaluation at individual level is technically challenging. We therefore investigated whether individual routine metabolic rate (RMR) was a predictor of individual FE in the European sea bass Dicentrarchus labrax, a major species in European mariculture. The European sea bass has three genetically distinct populations across its geographical range, namely Atlantic Ocean (AT), West Mediterranean (WM) and East Mediterranean (EM). We compared FE and RMR of fish from these three populations at $18^{\circ} \mathrm{C}$ or $24^{\circ} \mathrm{C}$. We held 200 fish $(62 \mathrm{AT}, 66 \mathrm{WM}$ and $72 \mathrm{EM}$ ) in individual aquaria and fed them from ad libitum down to fasting. Feed efficiency was assessed for an ad libitum feeding rate and for a fixed restricted ration (1\% of metabolic body weight.day ${ }^{-1}$, with metabolic body weight $=$ body weight ${ }^{0.8}$ ). After being refed 12 weeks in a common tank, individual RMR was measured over $36 \mathrm{~h}$ by intermittent flow respirometry. There was a significant effect of temperature whereby fish at $18^{\circ} \mathrm{C}$ had greater mean FE $(\mathrm{P}<0.05)$ and lower RMR $(\mathrm{P}<0.001)$. There was also a significant effect of population, where AT fish had lower FE $(\mathrm{P}<0.05)$ and greater RMR $(\mathrm{P}<0.001)$ than WM and EM, at both temperatures. Despite these differences in temperature and population means, individual FE and RMR were not significantly correlated $(\mathrm{P}>0.05)$. Therefore, although the 
44 results provide evidence of an association between metabolic rate and FE, RMR was not a

45 predictor of individual $\mathrm{FE}$, for reasons that require further investigation.

46 Key words: Aquaculture, genetic populations, individual rearing, oxygen consumption, 47 respirometry. 
49 AT, Atlantic

50 BW, body weight

51 BWG, body weight gain

52 BWG_1\%, body weight gain for a restricted feed intake set to $1 \%$ of metabolic body

53 weight.day ${ }^{-1}$

54 dph, days post hatch

55 EM, East Mediterranean

$56 \quad$ FE, feed efficiency

$57 \quad$ FI, feed intake

58 MBW, metabolic body weight

$59 \mathrm{MO}_{2}$, measurements of oxygen uptake

60 resBWG, residual body weight gain

61 RMR, routine metabolic rate

62 SMR, standard metabolic rate

63 WM, West Mediterranean 
Finfish aquaculture represents a promising source of sustainable animal protein for growing human populations globally (Godfray et al., 2010; Froehlich et al., 2018; FAO, 2018). A major factor in aquaculture sustainability is, however, feeding the fishes: it is the single greatest cost (Goddard, 1996) and a major determinant of environmental impact (Besson et al., 2016a). Feed efficiency (FE) is the ratio between fish body weight gain (BWG) and feed intake (FI); selective breeding to improve $\mathrm{FE}$ is a promising means to make aquaculture more sustainable (Besson et al., 2014; Besson et al., 2016a). Farmed fishes are, however, reared in large groups, where individual FI is technically very challenging to measure (Kause et al., 2006; Grima et al., 2008). An alternative is to rear individuals singly (Silverstein, 2006; Martins et al., 2011; Besson et al., 2019; Rodde et al., 2020), a technique that is widely used on terrestrial livestock (Luiting and Urff, 1991; de Haer and Merks, 1992; Nguyen et al., 2005; Drouilhet et al., 2016). This method has already been applied to European sea bass Dicentrarchus labrax, a major species for finfish aquaculture in Europe (Besson et al., 2019; Rodde et al., 2020). It involves holding hundreds of animals for several weeks, provided with individual daily rations, with all uneaten feed carefully collected and quantified each day (Besson et al., 2019; Rodde et al., 2020). In the European sea bass it returned reliable estimates of individual $\mathrm{FE}$, to the extent that individual $\mathrm{FE}$ in aquaria was clearly linked to the subsequent FE of groups, groups being composed of fish graded for individual FE (Besson et al., 2019). The method is, however, extremely time-consuming and laborious, which impedes its application on a large scale for selective breeding programs in aquaculture.

It is, therefore, useful to search for indirect selection criteria of individual FE, that are accurate predictors and can be measured more easily and rapidly. Bioenergetics is promising because it is assumed that energy intake from feed in fishes is allocated among several 
processes, most notably maintenance metabolism, activity and growth (Warren and Davis, 1967; Bureau et al., 2003). It is conceivable that, for a given feed intake, the most efficient individuals will be those that allocate the least energy to maintenance and activity, and the most to growth. In terrestrial livestock such as cattle, sheep and poultry, there is clear evidence of a negative correlation between individual metabolic rate and FE (Luiting et al., 1991; Nkrumah et al., 2006; Arndt et al., 2015; Chaves et al., 2015; Paganoni et al., 2017). Although there is some evidence of a link between metabolic rate and FE in groups of fishes (Kinghorn, 1983; Zeng et al., 2017), this remains to be demonstrated at an individual level. This study investigated whether individual metabolic rate, measured indirectly as rates of oxygen uptake, was a predictor of individual FE in the European sea bass. In this species, individual metabolic rate is negatively correlated with mass loss during fasting (Killen et al., 2011; McKenzie et al., 2014), indicating a link between metabolism and non-growth energy requirements, which could also relate to individual bioenergetics when feeding. Measuring individual oxygen consumption by respirometry on fasted (post-prandial) fish is technically quite simple and takes less than $48 \mathrm{~h}$ per animal (McKenzie et al., 2014).

Three genetically distinct populations of European sea bass have been identified across its natural geographical range: Atlantic (AT), West Mediterranean (WM) and East Mediterranean (EM; Guinand et al., 2017). These populations started to diverge 300,000 years ago (Duranton et al., 2018; Duranton et al., 2020) in environments whose temperatures differed along a North-West to South-East temperature gradient (Lindgren and Håkanson, 2011). European sea bass farming is by coastal cage mariculture so it is valuable to understand whether the populations may differ in their bioenergetics at different water temperatures, with potential implications for selection programs in different areas of Europe. Rodde et al. (2020) measured individual BWG and FI, over a range of feeding rates from ad libitum down to fasting, in 200 European sea bass from AT, WM and EM 
populations, at two temperatures, 18 and $24^{\circ} \mathrm{C}$. These two temperatures are representative of the coolest and warmest sites where European sea bass is reared across Europe (Vandeputte et al., 2014), and correspond to the average and optimal temperatures, respectively, that European sea bass undergoes when farmed in sea cages in the West Mediterranean (PersonLe Ruyet et al., 2004; Besson et al., 2016b). In the present study, we evaluated the metabolic rate of these individuals, by respirometry, at their acclimation temperatures. We then compared this to FE, of individuals and temperature by population combinations, considering when they were fed either ad libitum (their individual maximum energy intake) or with a fixed restricted ration of $1 \%$ individual body mass per day. Fish with greater metabolic rates may compensate by consuming more dietary energy than others when fed ad libitum but would be unable to do so on a fixed ration. That is, metabolic rate might be more closely related to FE when measured for a restricted ration compared to ad libitum. This study is, to our knowledge, the first to assess whether individual metabolic rate is a predictor of individual FE in farmed fish.

\section{Ethical Approval}

Experimental procedures were approved by C2EA-36 ("Comité d'éthique en expérimentation animale Languedoc-Roussillon”) under authorisations APAFiS nº 2018032109435819 and $n^{\circ} 2018100910598940$.

\section{Animals}

Complete details of how the fish were produced, reared and evaluated for their individual FE are provided in Rodde et al. (2020). Briefly, 200 European sea bass from the three populations (62 AT, $66 \mathrm{WM}$ and $72 \mathrm{EM}$ ) were produced on a single day by controlled breeding at the Ifremer Experimental Aquaculture Research Station (Palavas-les-Flots, 
France). Fish were reared at a mean $( \pm \mathrm{SD})$ temperature of $16.2 \pm 0.9^{\circ} \mathrm{C}$ from 0 to 97 days post hatch $(\mathrm{dph})$, then of $24.4 \pm 0.8^{\circ} \mathrm{C}$ from 98 to $152 \mathrm{dph}$, and finally of $21.1 \pm 1.0^{\circ} \mathrm{C}$ from 153 to $221 \mathrm{dph}$.

\section{Measurement of Individual Bodyweight Gain and Feed Intake}

When fish reached $221 \mathrm{dph}$ and a mean mass of $23.4 \pm 8.4 \mathrm{~g}$, they were transferred to an individual rearing system to estimate their individual FE. The individual rearing system consisted of two independent recirculating water systems, respectively set to 18 and $24^{\circ} \mathrm{C}$, each comprising 100 individual aquaria (vol. 10L), a sand filter, a biological filter and a ultraviolet filter. Feed, for the whole rearing period was a commercial diet called "Neo Start 3" (Le Gouessant Aquaculture, Lamballe, France). This diet was comprised of $47 \%$ of crude protein, $18 \%$ of crude fat, $1.5 \%$ of crude fibre, $8 \%$ of ash, $1 \%$ of phosphorus; digestible energy content was $19 \mathrm{MJ} . \mathrm{kg}^{-1}$, digestible protein/digestible energy ratio was $23 \mathrm{~g} \cdot \mathrm{MJ}^{-1}$. Feed was supplied once a day in the morning (9 a.m.) by automatic feeders set on the cover of each aquarium. The 200 aquaria were arranged on racks in the same room where they were shielded from visual disturbance, except once a day when uneaten feed was collected and quantified for each fish. Individuals could see their conspecifics in adjacent aquaria. Each aquarium received a constant supply of biofiltered aerated water at the appropriate temperature: water renewal was $300 \%$ per hour and mean oxygen saturation was $114.1 \%$ $\left(8.64 \mathrm{mg} \mathrm{O} 2 . \mathrm{L}^{-1}\right)$ and $107.1 \%\left(7.28 \mathrm{mg} \mathrm{O} \cdot \mathrm{L}^{-1}\right)$ at 18 and $24^{\circ} \mathrm{C}$, respectively. Mean water salinity was $37.2 \%$ and $37.4 \%$ at 18 and $24^{\circ} \mathrm{C}$, respectively, and mean water $\mathrm{pH}$ was 8.3 in both cases. Photoperiod was artificial: 12h light/12h dark (Rodde et al., 2020).

To acclimate fish to individual rearing, they were first held in groups of five per aquarium from 221 to $235 \mathrm{dph}$, then they were isolated and held, alone, for a further two weeks of acclimation. Once so acclimated, fish were fed incremental rations until their individual ad libitum feeding rate was identified, over three successive periods of seven days. 
Once individual ad libitum feeding rate was identified, fish were exposed to six sequential reductions in ration, from ad libitum (100\%), to $80 \%, 60 \%, 40 \%, 20 \%$ and then $0 \%$ (fasting). Fish were fed $100 \%$ ad libitum for 22 days, then for 10 to 11 days at the other steps; fish remained in isolation for 123 days (Rodde et al., 2020). Individual BWG and FI were measured at each step, to calculate fish FE ad libitum and at a ration of $1 \%$ individual body mass per day, see below.

After these trials, fish were grouped into two common tanks (vol. 1000L) supplied with biofiltered water at either $18^{\circ} \mathrm{C}$ or $24^{\circ} \mathrm{C}$ and fed ad libitum for 12 weeks. This period ensured that fish were in a stable nutritional state and that physiology and behaviour were not directly influenced by the feed deprivation or any stress linked to individual rearing (DupontPrinet et al., 2010; Rubio et al., 2010; McKenzie et al., 2014).

\section{Metabolic Rate by Respirometry}

One week before respirometry, fish were distributed among three holding tanks per temperature (vol. 1000L) supplied with biofiltered water. Single tanks were fasted for $24 \mathrm{~h}$ sequentially, and then, in the afternoon, up to 32 fish were netted, identified by a passive integrated transponder tag and weighed. The three tanks meant that fish were not disturbed by netting more than once every $72 \mathrm{~h}$. They were then placed into individual semi-transparent respirometry chambers (volume either 1.8 or $3.0 \mathrm{~L}$ ) according to their size, such that they were free to move easily, and left for $12 \mathrm{~h}$ (overnight) to recover from handling. There were 32 respirometry chambers, placed submerged on two polyvinyl chloride trays $(100 \times 200 \times 28$ cm) supplied with aerated biofiltered seawater at either $18^{\circ} \mathrm{C}$ or $24^{\circ} \mathrm{C}$. The trays were shielded behind opaque black plastic to avoid visual disturbance, with the fish in dim light at an artificial photoperiod of $12 \mathrm{~h}$ light/12h dark. In that system, individuals will have been aware of their conspecifics in adjacent chambers. 

respirometry (Steffensen, 1989) as described in McKenzie et al. (2014), but with a 15 minute cycle comprising eight minutes stopped flow and seven minutes flushing with aerated water. Water oxygen levels in the chambers were measured and recorded every ten seconds by optodes (Firesting OXROB10 oxygen sensors, www.pyroscience.com) and associated oxygen meter (Firesting FSO2-O4) and software (Pyro Oxygen Logger). During stopped flow, oxygen saturation in the chambers declined due to consumption by the fish, $\mathrm{MO}_{2}$ was calculated as $\mathrm{mg} \mathrm{O}_{2} \cdot \mathrm{kg}^{-1} \cdot \mathrm{h}^{-1}$ considering the volume of the chamber and the solubility of oxygen in seawater at 18 or $24^{\circ} \mathrm{C}$ and a salinity of $37 \%$ (Steffensen, 1989; Dupont-Prinet et al., 2010). After the $12 \mathrm{~h}$ recovery from handling, measurements were collected for $24 \mathrm{~h}$ on undisturbed fish. Upon removal of a batch from their chambers, background oxygen consumption due to bacterial respiration was measured over $20 \mathrm{~min}$ in the sealed chambers (Svendsen et al., 2016), this represented about $2 \%$ of the total oxygen consumption by the fish, so no correction was applied.

\section{Data Analysis and Statistics}

All statistical analyses were performed with R software (R Core Team, 2018). The normality of residuals was checked using the quantile-quantile method (comparing residuals quantiles with theoretical normal quantiles). The homoscedasticity and independence of the residuals were checked by comparing the residuals with the fitted values from the models. Linear mixed models and tests associated to these models were performed using $\mathrm{R}$ packages "Ime4" (Bates et al., 2015) and "ImerTest" (Kuznetsova et al., 2017).

Feed efficiency: Relationship between BWG and FI. The measures of BWG and FI were standardized to (divided by) metabolic body weight (MBW) instead of body weight (BW), based upon a mass exponent for metabolic rate of 0.8 in European sea bass (MBW = BW ${ }^{0.8}$; Lemarié et al., 1992; Lupatsch et al., 2003; Rodde et al., 2020). Both BWG and FI 
were then expressed as a percentage of MBW. The following repeated measures linear mixed model was used to estimate individual FE as residual BWG (resBWG) when fish were fed $a d$ libitum:

$B W G_{i j}=$ intercept + slope $* F I_{i j}+A_{j}+B_{j} * F I_{i j}+\operatorname{res} B W G_{i j}$ where $B W G_{i j}$ and $F I_{i j}$ are, respectively, the BWG and FI at step $i$ ( $i$ between 1 for ad libitum and 6 for fasting) for animal $j, A_{j}$ and $B_{j}$ are the random effects of the animal $j$, respectively, associated with intercept and slope, with $A_{j} \sim \mathrm{N}\left(0 ; \sigma^{2}\right.$ a), with $B_{j} \sim \mathrm{N}\left(0 ; \sigma^{2} \mathrm{~b}\right)$ and $\operatorname{res} B W G_{i j}$ the residual of the model $\left(r e s B W G_{i j} \sim \mathrm{N}\left(0 ; \sigma_{\mathrm{e}}^{2}\right)\right.$ ). From a biological point of view, the greater the resBWG, then the more efficient the individual. The model was calibrated on all the data from the six different feeding rates to increase its robustness, although only $\operatorname{res} B W G_{l j}$ (resBWG $a d$ libitum) were to be extracted from the model for further analyses.

Then, the following linear model was used for each fish to estimate the intercept and slope of the linear relationship between its BWG and FI:

$B W G_{i}=$ intercept + slope $* F I_{i}+\varepsilon_{i}$ where $B W G_{i}$ and $F I_{i}$ are respectively the BWG and FI at step $i$ ( $i$ between 1 for ad libitum and 6 for fasting) for each fish, and $\varepsilon_{i}$ the residual $\left(\varepsilon_{i j} \sim \mathrm{N}\left(0 ; \sigma_{\mathrm{e}}^{2}\right)\right)$. The intercept and slope of this relationship permitted to predict for each fish its BWG (in \% of MBW) for a restricted FI set to $1 \%$ of MBW.day ${ }^{-1}$, abbreviated as BWG_1\%, with BWG_1\%= intercept + slope* 1 .

Calculation of Metabolic Rates. Rates of oxygen uptake were corrected to (divided by) MBW, as per the measures of BWG and FI. Routine metabolic rate (RMR), defined as the metabolic rate of post-absorptive, undisturbed, resting animals at their acclimation temperature, which also includes the costs of random activity and the maintenance of posture and equilibrium (Killen et al., 2011), was taken as the mean rate of $\mathrm{MO}_{2}$ over 24h. Standard metabolic rate (SMR), defined as the minimal energetic cost of living for an ectotherm at their 
acclimation temperature, was estimated as the 0.25 quantile of $\mathrm{MO}_{2}$ values over the $24 \mathrm{~h}$ period (Chabot et al., 2016).

Variation in Phenotypic Traits between Temperatures and among Populations. The

following linear model was used to determine the variation of each trait at temperature and population levels:

$Y_{i j k}=\mu+T_{i}+P_{j}+T P_{i j}+\varepsilon_{i j k}$

where $\mathrm{Y}_{\mathrm{ijk}}$ is the phenotypic trait considered at temperature $\mathrm{i}\left(18^{\circ} \mathrm{C}\right.$ or $\left.24^{\circ} \mathrm{C}\right)$, for genetic population $\mathrm{j}$ (AT, WM or EM) and animal $\mathrm{k} ; \mu$ is the general mean, $\mathrm{T}$ is the fixed effect of temperature, $\mathrm{P}$ is the fixed effect of population, TP the interaction of these two effects, and $\varepsilon_{\mathrm{ijk}}$ the residuals $\left(\varepsilon_{\mathrm{ijk}} \sim \mathrm{N}\left(0 ; \sigma_{\mathrm{e}}^{2}\right)\right)$. Regarding the three populations, their pairwise differences were further explored using Tukey post-hoc test.

Link between Feed Efficiency and Metabolic Rate among Individuals. Pearson's correlation coefficient was estimated between traits of FE and metabolic rate, for each single temperature by population combination.

\section{RESULTS}

Among the 200 fish held, six died before the phenotyping period because they jumped out of their aquarium (five AT at $18^{\circ} \mathrm{C}$ and one AT at $24^{\circ} \mathrm{C}$ ). Of the 194 fish that were phenotyped in the aquaria, 46 failed to have a positive growth rate when fed ad libitum: seven AT out of 28 , five WM out of 34 and six EM out of 37 at $18^{\circ} \mathrm{C} ; 11$ AT out of $28,13 \mathrm{WM}$ out of 32 and four EM out of 35 at $24^{\circ} \mathrm{C}$. The resBWG and metabolic rate were not estimated for fish that lost weight ad libitum. For ethical reasons, if a fish had lost weight when fed ad libitum, or to $80 \%, 60 \%$ or $40 \%$ of ad libitum, the next step was fasting, with the fish then removed from the experiment. Moreover, five fish (two AT at $18^{\circ} \mathrm{C}$, two AT at $24^{\circ} \mathrm{C}$ and one $\mathrm{WM}$ at $\left.24^{\circ} \mathrm{C}\right)$ did not eat at all when fed ad libitum $(<1 \%$ of their BW over the 22 days) and were therefore removed from the experiment, without any fasting step. The individual linear 
model to calculate BWG_1\% was only applied to the 107 fish that were successively phenotyped for at least $100 \%, 80 \%, 60 \%$ and $0 \%$ of ad libitum feeding rate, to have at least four data to calibrate the individual linear model (Rodde et al., 2020).

Mean mass at the end of the individual rearing period was $31.3 \pm 12.0 \mathrm{~g}$ at $18^{\circ} \mathrm{C}$ and $35.4 \pm 11.4 \mathrm{~g}$ at $24^{\circ} \mathrm{C}$. After 12 weeks of ad libitum refeeding into common tanks, a threefold and fourfold increase in body mass was observed at 18 and $24^{\circ} \mathrm{C}$, respectively: when respirometry was performed, the mean mass was $99.0 \pm 29.7 \mathrm{~g}$ at $18^{\circ} \mathrm{C}$ and $146.2 \pm 40.4 \mathrm{~g}$ at $24^{\circ} \mathrm{C}$. Among the 148 fish that were successfully phenotyped ad libitum, 120 fish (18 AT, 19 $\mathrm{WM}$ and $25 \mathrm{EM}$ at $18^{\circ} \mathrm{C}$ and $14 \mathrm{AT}, 17 \mathrm{WM}$ and $27 \mathrm{EM}$ at $24^{\circ} \mathrm{C}$ ) had their metabolic rate successfully estimated. Moreover, among the 107 fish that had their BWG_1\% estimated, 92 fish (14 AT, $13 \mathrm{WM}$ and $22 \mathrm{EM}$ at $18^{\circ} \mathrm{C}$ and $7 \mathrm{AT}, 12 \mathrm{WM}$ and $24 \mathrm{EM}$ at $\left.24^{\circ} \mathrm{C}\right)$ had their metabolic rate successfully estimated.

\section{Variation in Phenotypic Traits between Temperatures and among Populations}

Firstly, resBWG (ad libitum feeding rate) as well as BWG_1\% were significantly different between temperatures $\left(\mathrm{F}_{1,126}=4.75, \mathrm{P}=3.11 \times 10^{-2}\right.$ and $\mathrm{F}_{1,103}=8.88, \mathrm{P}=3.59 \times 10^{-3}$, respectively) and among populations $\left(\mathrm{F}_{2,126}=7.25, \mathrm{P}=1.05 \times 10^{-3}\right.$ and $\mathrm{F}_{2,103}=12.32, \mathrm{P}=$ $1.59 \times 10^{-5}$, respectively). Both resBWG and BWG_1\% were greater at $18^{\circ} \mathrm{C}$ than at $24^{\circ} \mathrm{C}$, while the AT fish had significantly lower resBWG and BWG_1\% than WM fish $(\mathrm{P}=$ $2.30 \times 10^{-2}$ and $6.73 \times 10^{-3}$ with Tukey post-hoc test, respectively) and EM fish $\left(\mathrm{P}=1.02 \times 10^{-3}\right.$ and $\mathrm{P}=2.79 \times 10^{-5}$ with Tukey post-hoc test, respectively). These traits were not significantly different between $\mathrm{WM}$ and $\mathrm{EM}$ fish $(\mathrm{P}=0.70$ and $\mathrm{P}=0.31$, respectively). There was no temperature by population interaction $\left(\mathrm{F}_{2,124}=0.58, \mathrm{P}=0.56\right.$ and $\mathrm{F}_{2,101}=0.21, \mathrm{P}=0.81$, for resBWG and BWG_1\%, respectively).

Regarding RMR and SMR, means for temperatures and populations are presented in Table 1, with RMR values in Fig. 1. Firstly, RMR was positively and strongly correlated with 
SMR, whatever the temperature by population combination $(r=0.60-0.97)$. Thus, we chose to focus only on RMR results because SMR has very similar variations. Within each temperature by population combination, individual RMR was moderately variable with a CV (100*standard deviation/mean) between 9.8 and 14.8\%. Moreover, RMR differed significantly by temperature, with fish reared at $18^{\circ} \mathrm{C}$ having lower $\mathrm{RMR}\left(\mathrm{F}_{1,116}=130.89, \mathrm{P}<\right.$ $\left.2.2 \times 10^{-16}\right)$, but also by population $\left(\mathrm{F}_{2,116}=14.02, \mathrm{P}=3.52 \times 10^{-6}\right)$, whereby AT fish had a significantly greater RMR than WM and EM fish $\left(\mathrm{P}=1.95 \times 10^{-4}\right.$ and $\mathrm{P}=1.81 \times 10^{-4}$ respectively using Tukey post-hoc test). In contrast, the RMR of WM and EM fish was not significantly different $(\mathrm{P}=0.94)$. Moreover, there was no interaction effect between temperature and population on $\mathrm{RMR}\left(\mathrm{F}_{2,114}=1.67, \mathrm{P}=0.19\right)$.

\section{Correlation between Performance and RMR}

As illustrated in Fig. 2, a link between RMR and resBWG as well as BWG_1\% appears at temperature and populations levels. Indeed, fish at $18^{\circ} \mathrm{C}$ have a lower RMR and greater resBWG and BWG_1\% than $24^{\circ} \mathrm{C}$. Similarly, AT fish have a greater RMR and lower resBWG and BWG_1\% than WM and EM fish.

At the individual level, the correlations between RMR and resBWG ranged from -0.33 to 0.39 among the various temperature by population combinations (Fig. 3), but none of them was significant $(\mathrm{P}>0.05$ in all cases). Similarly, the correlations between RMR and BWG_1\% ranged from -0.43 to 0.15 among the various combinations (Fig. 4) and none of them was significant $(\mathrm{P}>0.05$ in all cases $)$.

\section{DISCUSSION}

This study is the first to attempt to relate individual variation in FE to metabolic rate in a farmed fish, the European sea bass. The results revealed effects of temperature and population on FE that could be linked to differences in RMR. No such relationships were observed at an individual level. 
The initial hypothesis made was that the most efficient fish, for a given feeding rate

( $1 \%$ of MBW.day ${ }^{-1}$ in the present study), were those allocating the least energy to

314 maintenance and activity, resulting in more available energy for growth. Present RMR results tend to valid this hypothesis between temperatures and among populations. Indeed, RMR differed in a consistent way with BWG_1\%: fish at $18^{\circ} \mathrm{C}$ were more efficient for $1 \%$ of MBW.day ${ }^{-1}$ and had a lower RMR that at $24^{\circ} \mathrm{C}$, AT fish were less efficient for $1 \%$ of MBW.day ${ }^{-1}$ and had a greater RMR than WM and EM fish.

Given that we estimated resBWG for fish fed ad libitum, it is perhaps surprising that it was also linked to RMR. It might have been suggested that fish with greater metabolic costs (i.e. RMR) would have compensated by increasing their ad libitum energy intake. However, our resBWG data suggest metabolic costs outweighed any potential compensation through an increased energy intake. This contrasts with Chinese crucian carp (Carassius auratus) where fish with greater RMR were less efficient under a restricted feeding rate but more efficient when fed at ad libitum (Zeng et al., 2017). This difference in results may be explained by the fact that fish were reared as a group by Zeng et al. (2017) but individually in the present study. Indeed, in the present study, ad libitum FI ranged from 0.53 to $0.73 \%$ and from 0.85 to $1.12 \%$ of BW.day ${ }^{-1}$ at $18^{\circ} \mathrm{C}$ and $24^{\circ} \mathrm{C}$, respectively (Rodde at al., 2020). This is low compared to what could be expected in group rearing: around $1.1 \%$ and $1.7 \%$ of BW.day ${ }^{-1}$ at $18^{\circ} \mathrm{C}$ and $24^{\circ} \mathrm{C}$, respectively, according to the model developed by Lanari et al. (2002) for European sea bass. It suggests that European sea bass do not achieve their full feed consumption potential during individual rearing.

The fact that RMR was greater in fish reared at $24^{\circ} \mathrm{C}$ than in those reared at $18^{\circ} \mathrm{C}$ is not surprising: oxygen consumption is known to increase with temperature in every fish species (meta-analysis by Clarke and Johnston, 1999), including European sea bass 
(Claireaux and Lagardère, 1999). In contrast, it is very interesting that AT fish had a greater RMR than the two Mediterranean populations. This has, to our knowledge, never been reported before, although they are known to be genetically distinct (Duranton et al., 2018) and differ in other phenotypic traits such as growth, sex ratio, muscle fat or resistance to viral nervous necrosis (Guinand et al., 2017; Doan et al., 2017; Vandeputte at al., 2019). One event that may have provided a genetic basis for differences in metabolic rate among the populations is an ancient admixture between the Atlantic European sea bass and the closely related Dicentrarchus punctatus (Duranton et al., 2020). This led to the subsequent rapid fixation of some D. punctatus alleles in the Atlantic D. labrax and to the establishment of reproductive isolation barriers between Atlantic and Mediterranean populations (Duranton et al., 2020).

The phenotypic traits underlying such differences among populations in metabolic rate still need to be determined. It seems unlikely that variation is due to behavioural differences, because RMR was so strongly correlated with SMR, which indicates that animals were routinely very close to their basal metabolism. This can be explained by the fact that fish exhibited little swimming activity while in the individual respirometry chamber. Even if the experimental set-up avoided any disturbance from the outside, such little activity appears surprising. This may be due to the fact these fish had already experienced 123 days in isolated aquaria before being evaluated for RMR. Thus, the fish used here were probably more acclimated to isolation than usual, resulting in a low swimming activity. Other factors may be account for the RMR differences among populations. For instance, greater RMR might be associated to bigger sizes of metabolically expensive organs such as heart, liver or brain (Konarzewski and Książek, 2013), greater mitochondrial density (i.e. energy consumption per unit mass of tissue), greater activity of mitochondrial enzymes or lower ATP production efficiency (i.e. ATP produced per unit consumption of oxygen; Norin and Metcalfe, 2019). 
Investigating these various hypotheses could provide a better understanding of the factors underlying RMR variation among populations.

\section{Link between Feed Efficiency and RMR at Individual Level}

Differences observed between temperatures and among populations revealed a consistent link between high FE performance and low RMR, whatever the feeding rate. In contrast, no correlation appeared at the individual level, no matter if the feeding rate was restricted $\left(1 \%\right.$ of MWB.day $\left.{ }^{-1}\right)$ or not (ad libitum). Nevertheless, there is a need for further investigation before concluding that RMR is of no use to improve FE in a selective breeding program.

Firstly, only genetic correlations permit the conclusion whether a trait can be selected indirectly using another trait. At the individual level, a CV of 9.8 to $14.8 \%$ was found for RMR. Similarly, Killen et al. (2011) found a CV of 13\% for European sea bass RMR, measured by the same respirometry method and then corrected for metabolic body weight. There is a need to determine whether this phenotypic variation in RMR has any heritable genetic component. However, setting up an experimental design to estimate genetic correlations is technically challenging. The number of fish phenotyped for both FE and RMR would need to be multiplied by at least four or five in comparison with the present study. Moreover, fish BWG and FI performance were measured before RMR, and not simultaneously. The time lapse between these measurements was 12 weeks and fish had their weight multiplied by four, so their development stage was not similar, and this may explain why a correlation was not found. Metabolic rate estimation is known to have a moderate short term-repeatability in European sea bass $(r=0.48$ for measurements separated by 20 minutes; Marras et al., 2010), but its longer term repeatability is, to our knowledge, unknown in this species. This is problematic because long-term repeatability of metabolic rate may be speciesspecific. For instance, it was reported as high $(r=0.68$ for measurements separated by 17 
weeks) in Atlantic salmon Salmo salar (McCarthy, 2000) but as very low (r $=0.093$ for measurements separated by 15 weeks) in brown trout Salmo trutta (Norin and Malte, 2011). Similarly, the long-term repeatability of individual FE is completely unknown in the European sea bass. Since it is not technically feasible to estimate individual FE and RMR simultaneously, further investigation of both traits' long-term repeatability is needed. It is also unknown whether the type of reserves, i.e. proteins or lipids, on which each fish relies the most to produce its energy. Indeed, lipids provide twice as much energy as proteins do for an equal weight. Thus, to ensure equal maintenance costs, fish degrading lipids will consume a lower mass of reserves than fish degrading proteins. For instance, McKenzie et al. (2014) reported that European sea bass relying on proteins rather than on lipids to produce energy while fasting were losing more weight. Consequently, a link between the main type of reserves used and individual FE may exist. In particular, AT fish muscle fat content is greater than in the Mediterranean populations (Vandeputte et al., 2014; F. Allal, personal communication, 2020). Thus, AT fish might use their lipid reserves less than Mediterranean populations (and so they tend to accumulate them), degrading their protein reserves instead. This could explain why AT fish are ultimately less efficient. This hypothesis is supported by results reported in several species such as pig or rainbow trout showing the most efficient animals had the lowest muscle fat content (Kamalam et al., 2012; Kause et al., 2016; Knap and Kause, 2018).

Our results demonstrated variation among European sea bass populations regarding oxygen consumption, in addition to the well-known effect of temperature on this trait.

Between temperatures and among populations, fish with a lower oxygen consumption were more efficient. However, at the individual level, no significant correlation was found. Further investigation is still required to fully understand the link between individual FE and oxygen consumption in fish. 
Arndt, C., J. M. Powell, M. J. Aguerre, P. M. Crump, and M. A. Wattiaux. 2015. Feed conversion efficiency in dairy cows: Repeatability, variation in digestion and metabolism of energy and nitrogen, and ruminal methanogens. J. Dairy Sci.

416 98:3938-3950. doi:10.3168/jds.2014-8449.

Bates, D., M. Mächler, B. Bolker, and S. Walker. 2015. Fitting linear mixed-effects models using lme4. J. Stat. Softw. 67:1-

418 48. doi:10.18637/jss.v067.i01.

Besson, M., H. Komen, J. Aubin, I. J. M. de Boer, M. Poelman, E. Quillet, C. Vancoillie, M. Vandeputte, and J. A. M. van Arendonk. 2014. Economic values of growth and feed efficiency for fish farming in recirculating aquaculture system with density and nitrogen output limitations: a case study with African catfish (Clarias gariepinus). J. Anim. Sci. 92:5394-5405. doi:10.2527/jas.2014-8266.

Besson, M., J. Aubin, H. Komen, M. Poelman, E. Quillet, M. Vandeputte, J. A. M. van Arendonk, and I. J. M. de Boer. 2016a. Environmental impacts of genetic improvement of growth rate and feed conversion ratio in fish farming under rearing density and nitrogen output limitations. J. Clean. Prod. 116:100-109. doi:10.1016/j.jclepro.2015.12.084.

Besson, M., M. Vandeputte, J. A. M. van Arendonk, J. Aubin, I. J. M. de Boer, E. Quillet, and H. Komen. 2016b. Influence of water temperature on the economic value of growth rate in fish farming: The case of sea bass (Dicentrarchus labrax) cage farming in the Mediterranean. Aquaculture. 462:47-55. doi:10.1016/j.aquaculture.2016.04.030.

Besson, M., F. Allal, B. Chatain, A. Vergnet, F. Clota, and M. Vandeputte. 2019. Combining individual phenotypes of feed intake with genomic data to improve feed efficiency in sea bass. Front. Genet. 10:219. doi:10.3389/fgene.2019.00219.

Bureau, D. P., S. J. Kaushik, and C. Y. Cho. 2003. 1 - Bioenergetics. In: J. E. Halver and R. W. Hardy, editors, Fish Nutrition (Third Edition). Academic Press, San Diego, CA. p. 1-59.

Chabot, D., J. F. Steffensen, and A. P. Farrell. 2016. The determination of standard metabolic rate in fishes. J. Fish Biol. 88:81-121. doi:10.1111/jfb.12845.

Chaves, A. S., M. L. Nascimento, R. R. Tullio, A. N. Rosa, M. M. Alencar, and D. P. Lanna. 2015. Relationship of efficiency indices with performance, heart rate, oxygen consumption, blood parameters, and estimated heat production in Nellore steers. J. Anim. Sci. 93:5036-5046. doi:10.2527/jas.2015-9066.

Claireaux, G., and J.-P. Lagardère. 1999. Influence of temperature, oxygen and salinity on the metabolism of the European sea bass. J. Sea Res. 42:157-168. doi:10.1016/S1385-1101(99)00019-2.

Clarke, A., and N. M. Johnston. 1999. Scaling of metabolic rate with body mass and temperature in teleost fish. J. Anim.

de Haer, L. C. M., and J. W. M. Merks. 1992. Patterns of daily food intake in growing pigs. Anim. Sci. 54:95-104. doi:10.1017/S0003356100020614.

Doan Q., K., M. Vandeputte, B. Chatain, P. Haffray, A. Vergnet, G. Breuil, and F. Allal. 2017. Genetic variation of resistance to Viral Nervous Necrosis and genetic correlations with production traits in wild populations of the European sea bass (Dicentrarchus labrax). Aquaculture. 478:1-8. doi:10.1016/j.aquaculture.2017.05.011.

Drouilhet, L., C. S. Achard, O. Zemb, C. Molette, T. Gidenne, C. Larzul, J. Ruesche, A. Tircazes, M. Segura, T. Bouchez, M. Theau-Clément, T. Joly, E. Balmisse, H. Garreau, and H. Gilbert. 2016. Direct and correlated responses to selection in two lines of rabbits selected for feed efficiency under ad libitum and restricted feeding: I. Production traits and gut microbiota characteristics. J. Anim. Sci. 94:38-48. doi:10.2527/jas.2015-9402. 
Duranton, M., F. Allal, C. Fraïsse, N. Bierne, F. Bonhomme, and P.-A. Gagnaire. 2018. The origin and remolding of genomic islands of differentiation in the European sea bass. Nat. Commun. 9:2518. doi:10.1038/s41467-018-04963-6.

Duranton, M., F. Allal, S. Valière, O. Bouchez, F. Bonhomme, and P.-A. Gagnaire. 2020. The contribution of ancient admixture to reproductive isolation between European sea bass lineages. Evol. Lett. 4:226-242. doi:10.1002/evl3.169.

FAO. 2018. The State of World Fisheries and Aquaculture 2018 - Meeting the sustainable development goals. Food and Agriculture Organization of the United Nations, Rome, Italy.

Froehlich, H. E., C. A. Runge, R. R. Gentry, S. D. Gaines, and B. S. Halpern. 2018. Comparative terrestrial feed and land use of an aquaculture-dominant world. Proc. Natl. Acad. Sci. U.S.A. 115:5295-5300. doi:10.1073/pnas.1801692115.

Goddard, J. 1996. Feed Management in Intensive Aquaculture. Chapman and Hall, New York, NY.

Godfray, H. C. J., J. R. Beddington, I. R. Crute, L. Haddad, D. Lawrence, J. F. Muir, J. Pretty, S. Robinson, S. M. Thomas, and C. Toulmin. 2010. Food security: The challenge of feeding 9 billion people. Science. 327:812-818. doi:10.1126/science.1185383.

Grima, L., E. Quillet, T. Boujard, C. Robert-Granié, B. Chatain, and M. Mambrini. 2008. Genetic variability in residual feed intake in rainbow trout clones and testing of indirect selection criteria. Genet. Sel. Evol. 40:607-624. doi:10.1186/12979686-40-6-607.

Guinand, B., M. Vandeputte, M. Dupont-Nivet, A. Vergnet, P. Haffray, H. Chavanne, and B. Chatain. 2017. Metapopulation patterns of additive and nonadditive genetic variance in the sea bass (Dicentrarchus labrax). Ecol. Evol. 7:2777-2790. doi:10.1002/ece3.2832.

Kamalam, B. S., F. Medale, S. Kaushik, S. Polakof, S. Skiba-Cassy, and S. Panserat. 2012. Regulation of metabolism by dietary carbohydrates in two lines of rainbow trout divergently selected for muscle fat content. J. Exp. Biol. 215:2567-2578. doi:10.1242/jeb.070581.

Kause, A., D. Tobin, A. Dobly, D. Houlihan, S. Martin, E. A. Mäntysaari, O. Ritola, and K. Ruohonen. 2006. Recording strategies and selection potential of feed intake measured using the X-ray method in rainbow trout. Genet. Sel. Evol. 38:389409. doi:10.1186/1297-9686-38-4-389.

Kause, A., A. Kiessling, S. A. M. Martin, D. Houlihan, and K. Ruohonen. 2016. Genetic improvement of feed conversion ratio via indirect selection against lipid deposition in farmed rainbow trout (Oncorhynchus mykiss Walbaum). Br. J. Nutr. 116:1656-1665. doi:10.1017/S0007114516003603.

Killen, S. S., S. Marras, and D. J. McKenzie. 2011. Fuel, fasting, fear: routine metabolic rate and food deprivation exert synergistic effects on risk-taking in individual juvenile European sea bass. J. Anim. Ecol. 80:1024-1033. doi:10.1111/j.13652656.2011.01844.x.

Kinghorn, B. 1983. Genetic variation in food conversion efficiency and growth in rainbow trout. Aquaculture. 32:141-155. doi:10.1016/0044-8486(83)90276-4.

Knap, P. W., and A. Kause. 2018. Phenotyping for genetic improvement of feed efficiency in fish: Lessons from pig breeding. Front. Genet. 9:184. doi:10.3389/fgene.2018.00184.

Konarzewski, M., and A. Książek. 2013. Determinants of intra-specific variation in basal metabolic rate. J. Comp. Physiol. B, Biochem. Syst. Environ. Physiol. 183:27-41. doi:10.1007/s00360-012-0698-z.

Kuznetsova, A., P. B. Brockhoff, and R. H. B. Christensen. 2017. ImerTest Package: Tests in Linear Mixed Effects Models. J. Stat. Softw. 82:1-26. doi:10.18637/jss.v082.i13.

Lanari, D., E. D’Agaro, and R. Ballestrazzi. 2002. Growth parameters in European sea bass (Dicentrarchus labrax L.): Effects of live weight and water temperature. Ital. J. Anim. Sci. 1:181-185. doi:10.4081/ijas.2002.181.

Lemarié, G., E. Gasset, D. Cam, and E. de la Fonchais. 1992. Modélisation de la consommation en oxygène du loup (Dicentarchus labrax L.) et de la daurade (Sparus aurata L.). Ichtyophysiologica Acta. 15:55-68.

Lindgren, D., and L. Håkanson. 2011. Morphometric classification and GIS-based data analysis in coastal modeling and management. Open Environ. Sci. 511:1-17. doi:10.2174/1876325101105010001.

Luiting, P., and E. M. Urff. 1991. Optimization of a model to estimate residual feed consumption in the laying hen. Livest. 
Luiting, P., J. W. Schrama, W. van der Hel, and E. M. Urff. 1991. Metabolic differences between White Leghorns selected for high and low residual food consumption. Br. Poult. Sci. 32:763-782. doi:10.1080/00071669108417402.

Lupatsch, I., G. W. Kissil, and D. Sklan. 2003. Comparison of energy and protein efficiency among three fish species gilthead sea bream (Sparus aurata), European sea bass (Dicentrarchus labrax) and white grouper (Epinephelus aeneus): Energy expenditure for protein and lipid deposition. Aquaculture. 225:175-189. doi:10.1016/S0044-8486(03)00288-6.

Marras, S., G. Claireaux, D. J. McKenzie, and J. A. Nelson. 2010. Individual variation and repeatability in aerobic and anaerobic swimming performance of European sea bass, Dicentrarchus labrax. J. Exp. Biol. 213:26-32. doi:10.1242/jeb.032136.

Martins, C. I. M., L. E. C. Conceição, and J. W. Schrama. 2011. Feeding behavior and stress response explain individual differences in feed efficiency in juveniles of Nile tilapia Oreochromis niloticus. Aquaculture. 312:192-197.

510 doi:10.1016/j.aquaculture.2010.12.035.

McCarthy, I. D. 2000. Temporal repeatability of relative standard metabolic rate in juvenile Atlantic salmon and its relation to life history variation. J. Fish Biol. 57:224-238. doi:10.1111/j.1095-8649.2000.tb00788.x.

McKenzie, D. J., A. Vergnet, B. Chatain, M. Vandeputte, E. Desmarais, J. F. Steffensen, and B. Guinand. 2014.

Dicentrarchus labrax. J. Exp. Biol. 217:3283-3292. doi:10.1242/jeb.101857.

Nguyen, N. H., C. P. McPhee, and C. M. Wade. 2005. Responses in residual feed intake in lines of Large White pigs selected for growth rate on restricted feeding (measured on ad libitum individual feeding). J. Anim. Breed. Genet. 122:264-270. doi:10.1111/j.1439-0388.2005.00531.x.

Nkrumah, J. D., E. K. Okine, G. W. Mathison, K. Schmid, C. Li, J. A. Basarab, M. A. Price, Z. Wang, and S. S. Moore. 2006. Relationships of feedlot feed efficiency, performance, and feeding behavior with metabolic rate, methane production, and energy partitioning in beef cattle. J. Anim. Sci. 84:145-153. doi:10.2527/2006.841145x.

Norin, T., and H. Malte. 2011. Repeatability of standard metabolic rate, active metabolic rate and aerobic scope in young brown trout during a period of moderate food availability. J. Exp. Biol. 214:1668-1675. doi:10.1242/jeb.054205.

Norin, T., and N. B. Metcalfe. 2019. Ecological and evolutionary consequences of metabolic rate plasticity in response to environmental change. Phil. Trans. R. Soc. B 374:20180180. doi:10.1098/rstb.2018.0180.

Paganoni, B., G. Rose, C. Macleay, C. Jones, D. J. Brown, G. Kearney, M. Ferguson, and A. N. Thompson. 2017. More feed efficient sheep produce less methane and carbon dioxide when eating high-quality pellets. J. Anim. Sci. 95:3839-3850. doi:10.2527/jas.2017.1499.

Person-Le Ruyet, J., K. Mahé, N. Le Bayon, and H. Le Delliou. 2004. Effects of temperature on growth and metabolism in a Mediterranean population of European sea bass, Dicentrarchus labrax. Aquaculture. 237:269-280. doi:10.1016/j.aquaculture.2004.04.021.

R Core Team, 2018. R: A Language and Environment for Statistical Computing. R foundation for Statistical Computing, Vienna, Austria. URL: http://www.R-project.org/

Rodde, C., M. Vandeputte, F. Allal, M. Besson, F. Clota, A. Vergnet, J. A. H. Benzie, and H. de Verdal. 2020. Population, temperature and feeding rate effects on individual feed efficiency in European sea bass (Dicentrarchus labrax). Front. Mar. Sci. 7:578976. doi:10.3389/fmars.2020.578976.

Rubio, V. C., E. Sánchez, and J. M. Cerdá-Reverter. 2010. Compensatory feeding in the sea bass after fasting and physical stress. Aquaculture. 298:332-337. doi:10.1016/j.aquaculture.2009.10.031.

Silverstein, J. T. 2006. Relationships among feed intake, feed efficiency, and growth in juvenile rainbow trout. N. Am. J. Aquac. 68:168-175. doi:10.1577/A05-010.1.

Steffensen, J. F. 1989. Some errors in respirometry of aquatic breathers: How to avoid and correct for them. Fish. Physiol. Biochem. 6:49-59. doi:10.1007/BF02995809.

Svendsen, M. B. S., P. G. Bushnell, and J. F. Steffensen. 2016. Design and setup of intermittent-flow respirometry system for aquatic organisms. J. Fish Biol. 88:26-50. doi: 10.1111/jfb.12797. 
Vandeputte, M., R. Garouste, M. Dupont-Nivet, P. Haffray, A. Vergnet, H. Chavanne, S. Laureau, T. B. Ron, G. Pagelson, C. Mazorra, R. Ricoux, P. Marques, M. Gameiro, and B. Chatain. 2014. Multi-site evaluation of the rearing performances of 5 wild populations of European sea bass (Dicentrarchus labrax). Aquaculture. 424-425:239-248. doi:10.1016/j.aquaculture.2014.01.005.

Warren, C. E., and G. E. Davis. 1967. Laboratory studies on the feeding, bioenergetics and growth of fish. In: S. D. Gerking, editor. The Biological Basis of Freshwater Fish Production. Wiley and Sons, New York, NY. p. 175-214.

Zeng, L.-Q., A.-J. Zhang, S. S. Killen, Z.-D. Cao, Y.-X. Wang, and S.-J. Fu. 2017. Standard metabolic rate predicts growth trajectory of juvenile Chinese crucian carp (Carassius auratus) under changing food availability. Biol. Open 6:1305-1309. doi:10.1242/bio.025452. 
Table 1. Mean \pm standard deviation $(100 *$ standard deviation/mean) of routine metabolic rate (RMR), standard metabolic rate (SMR) and weight at respirometry. Results are presented for Atlantic (AT), West Mediterranean (WM) and East Mediterranean (EM) populations reared at $18^{\circ} \mathrm{C}$ or $24^{\circ} \mathrm{C}$. Within each combination of temperature by population, the correlation between RMR and SMR is given with P-value, as well as the number of fish

Fig. 1. Routine metabolic rate (RMR) values observed for each combination of temperature by population. Results are presented for Atlantic (AT), West Mediterranean (WM) and East Mediterranean (EM) populations reared at $18^{\circ} \mathrm{C}$ or $24^{\circ} \mathrm{C}$. In the box and whisker plots presented, the box lower and upper limits are respectively the 0.25 and 0.75 quantiles of the RMR data and the box is divided by the median of the values. The whiskers lower and upper ends are respectively the lowest and greatest RMR values. Dots represent each fish RMR

Fig. 2. A) Residual body weight gain at ad libitum feeding rate as a function of routine metabolic rate (RMR) among temperature by population combinations. B) Predicted body weight gain as a function of RMR among temperature by population combinations. Predicted body weight gain is expressed in \% of metabolic body weight (MBW) and is corresponding a

572 level of feed intake set to $1 \%$ of $\mathrm{MBW} \mathrm{day}^{-1}$. Results are presented for Atlantic (AT), West

573 Mediterranean (WM) and East Mediterranean (EM) populations reared at $18^{\circ} \mathrm{C}$ or $24^{\circ} \mathrm{C}$.

574 Horizontal and vertical bars associated to each point are corresponding to standard errors

575 Fig. 3. Individual residual body weight gain at ad libitum feeding rate as a function of

576 individual routine metabolic rate (RMR). Results are presented for Atlantic (AT), West

577 Mediterranean (WM) and East Mediterranean (EM) populations reared at $18^{\circ} \mathrm{C}$ or $24^{\circ} \mathrm{C}$. The 578 straight lines represent the linear regressions of individual residual body weight gain as a function of individual RMR in each case 
580 Fig. 4. Individual predicted body weight gain as a function of individual routine metabolic

581 rate (RMR). Predicted body weight gain is expressed in \% of metabolic body weight (MBW)

582 and is corresponding a level of feed intake set to $1 \%$ of MBW.day ${ }^{-1}$. Results are presented for

583 Atlantic (AT), West Mediterranean (WM) and East Mediterranean (EM) populations reared at

$58418^{\circ} \mathrm{C}$ or $24^{\circ} \mathrm{C}$. The straight lines represent the linear regressions of individual predicted

585 weight gain as a function of individual RMR in each case

586 
588 Mean \pm standard deviation $(100 *$ standard deviation/mean) of routine metabolic rate (RMR),

589 standard metabolic rate (SMR) and weight at respirometry. Results are presented for Atlantic

590 (AT), West Mediterranean (WM) and East Mediterranean (EM) populations reared at $18^{\circ} \mathrm{C}$ or

$59124^{\circ} \mathrm{C}$. Within each combination of temperature by population, the correlation between RMR

592 and SMR is given with P-value, as well as the number of fish

\begin{tabular}{|c|c|c|c|c|c|}
\hline & $\begin{array}{c}\text { RMR, } \\
\mathrm{mg} \mathrm{O2.kg}^{-0.8} \cdot \mathrm{h}^{-1}\end{array}$ & $\begin{array}{c}\text { SMR, } \\
\text { mg O2.kg }{ }^{-0.8} \cdot \mathrm{h}^{-1}\end{array}$ & $\begin{array}{c}\text { Weight at } \\
\text { respirometry, g }\end{array}$ & $\begin{array}{c}\text { Correlation } \\
\text { between RMR and } \\
\text { SMR (P-value) }\end{array}$ & $\begin{array}{c}\text { Number } \\
\text { of fish }\end{array}$ \\
\hline \multicolumn{6}{|l|}{ Combinations } \\
\hline $\mathrm{AT} \times 18^{\circ} \mathrm{C}$ & $78.7 \pm 8.0(10.2)$ & $67.8 \pm 4.7(7.0)$ & $107.6 \pm 34.9(32.5)$ & $0.60(\mathrm{P}<0.01)$ & 18 \\
\hline $\mathrm{WM} \times 18^{\circ} \mathrm{C}$ & $70.1 \pm 6.9(9.8)$ & $63.8 \pm 5.8(9.1)$ & $80.0 \pm 20.8(25.9)$ & $0.88(\mathrm{P}<0.001)$ & 19 \\
\hline $\mathrm{EM} \times 18^{\circ} \mathrm{C}$ & $70.3 \pm 9.0(12.9)$ & $65.4 \pm 7.2(11.0)$ & $107.2 \pm 25.5(23.8)$ & $0.92(\mathrm{P}<0.001)$ & 25 \\
\hline $\mathrm{AT} \times 24^{\circ} \mathrm{C}$ & $108.5 \pm 15.7(14.5)$ & $86.8 \pm 13.9(16.0)$ & $142.2 \pm 39.8(28.0)$ & $0.83(\mathrm{P}<0.001)$ & 14 \\
\hline $\mathrm{WM} \times 24^{\circ} \mathrm{C}$ & $91.9 \pm 12.1(13.2)$ & $80.7 \pm 10.4(12.8)$ & $125.5 \pm 26.9(21.4)$ & $0.91(\mathrm{P}<0.001)$ & 17 \\
\hline $\mathrm{EM} \times 24^{\circ} \mathrm{C}$ & $91.3 \pm 13.6(14.8)$ & $80.8 \pm 13.1(16.2)$ & $161.3 \pm 42.7(26.5)$ & $0.97(\mathrm{P}<0.001)$ & 27 \\
\hline
\end{tabular}

593

594 


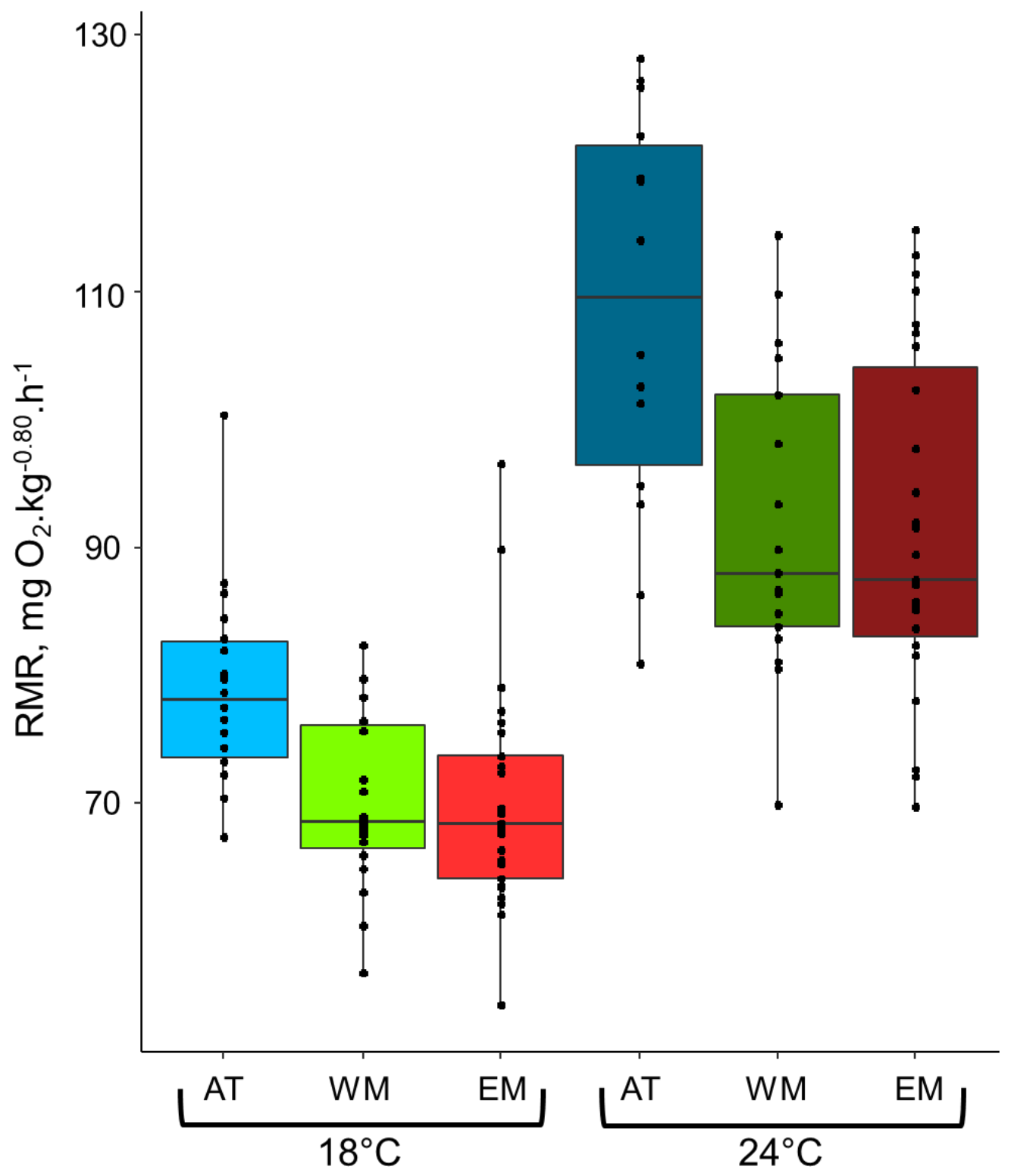

595

Fig. 1. 


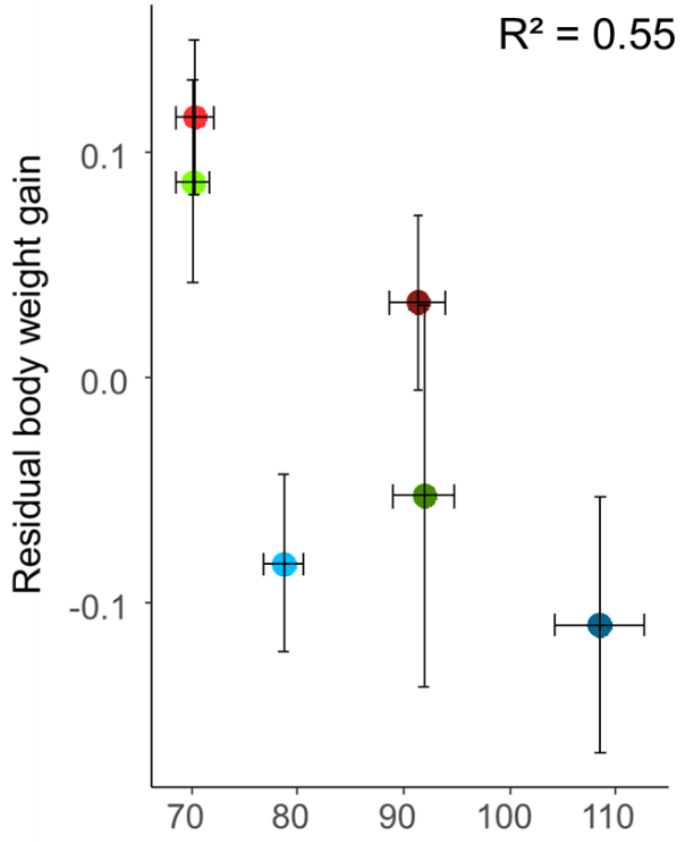

A RMR, $\mathrm{mg} \mathrm{O}_{2} \cdot \mathrm{kg}^{-0.80} \cdot \mathrm{h}^{-1}$

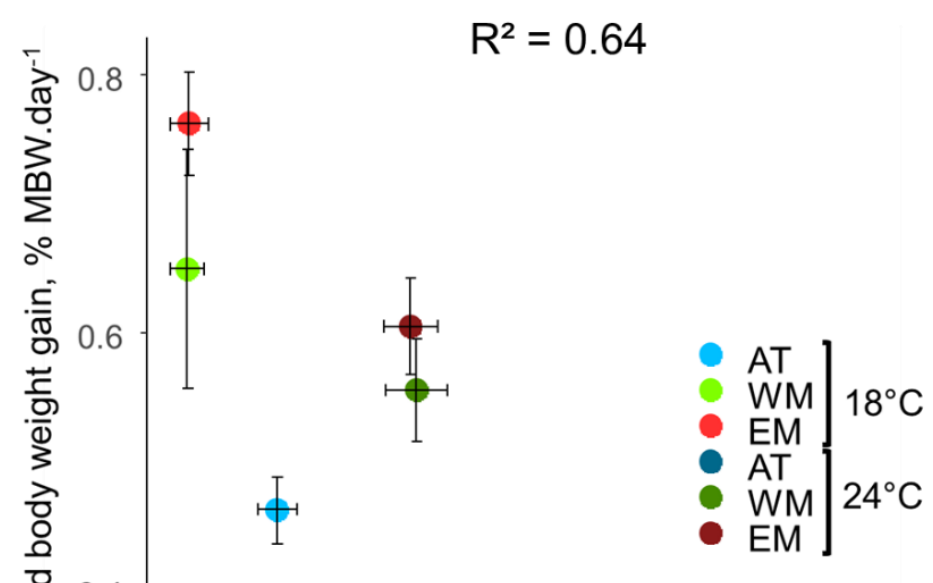

Fig. 2. 

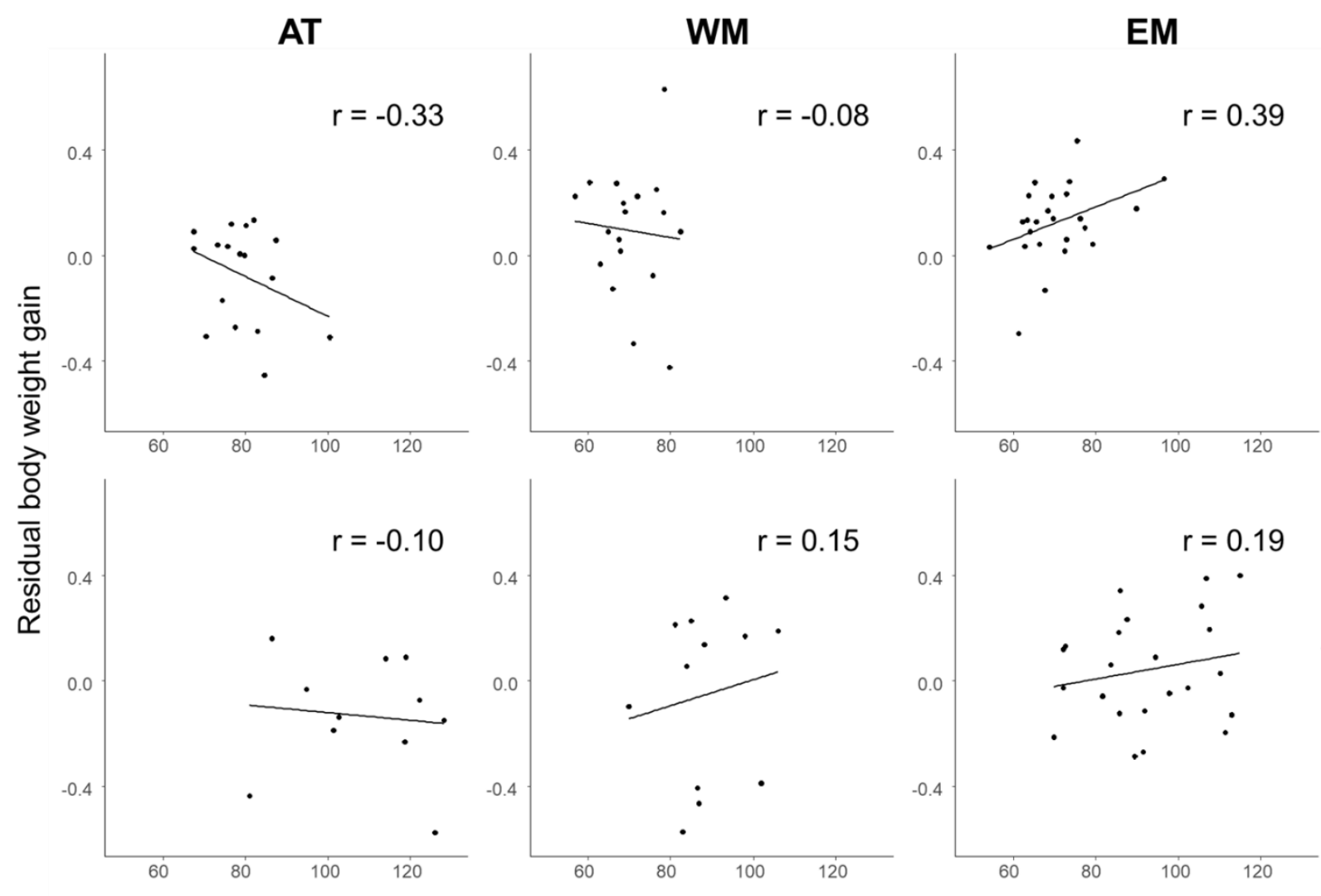

$18^{\circ} \mathrm{C}$

599
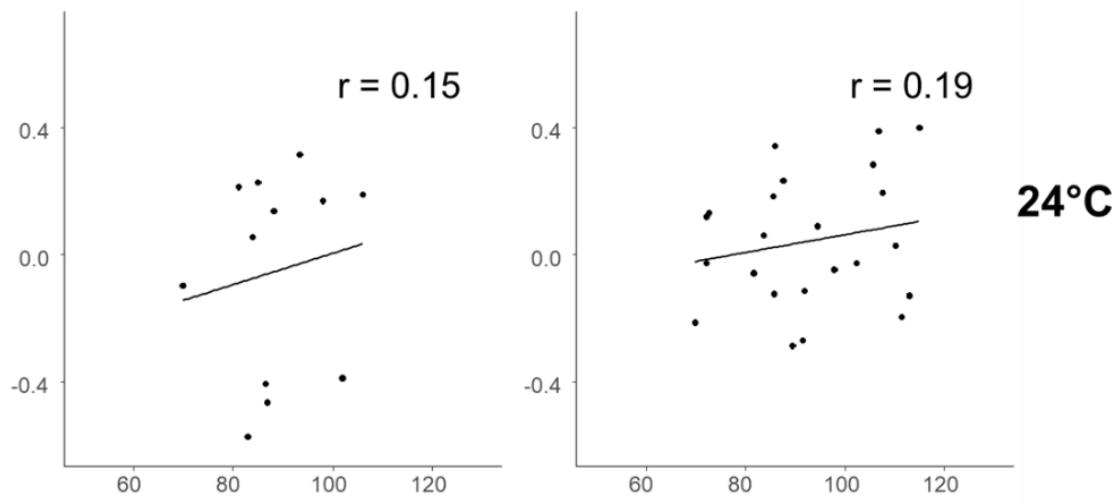

600

Fig. 3. 

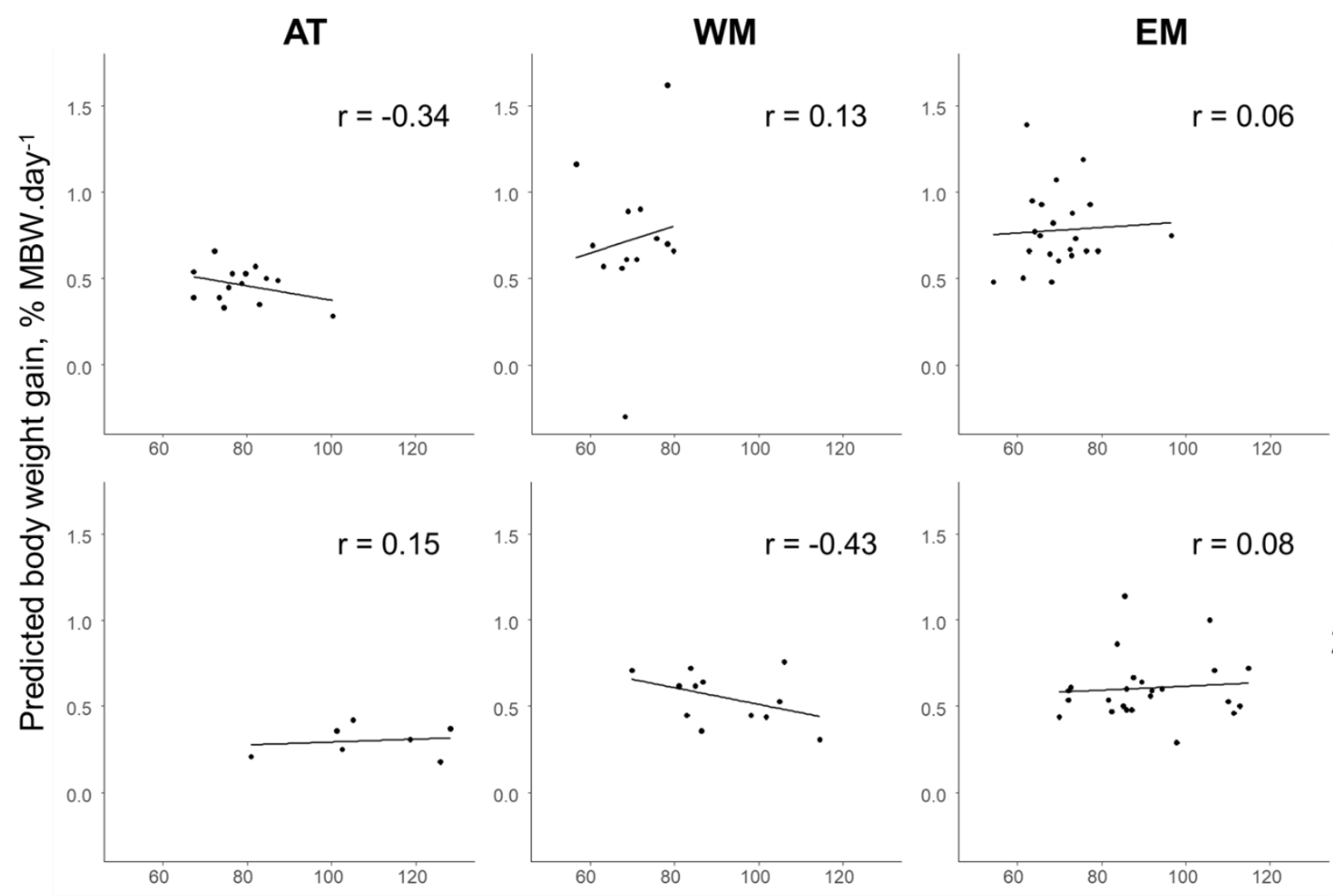

601
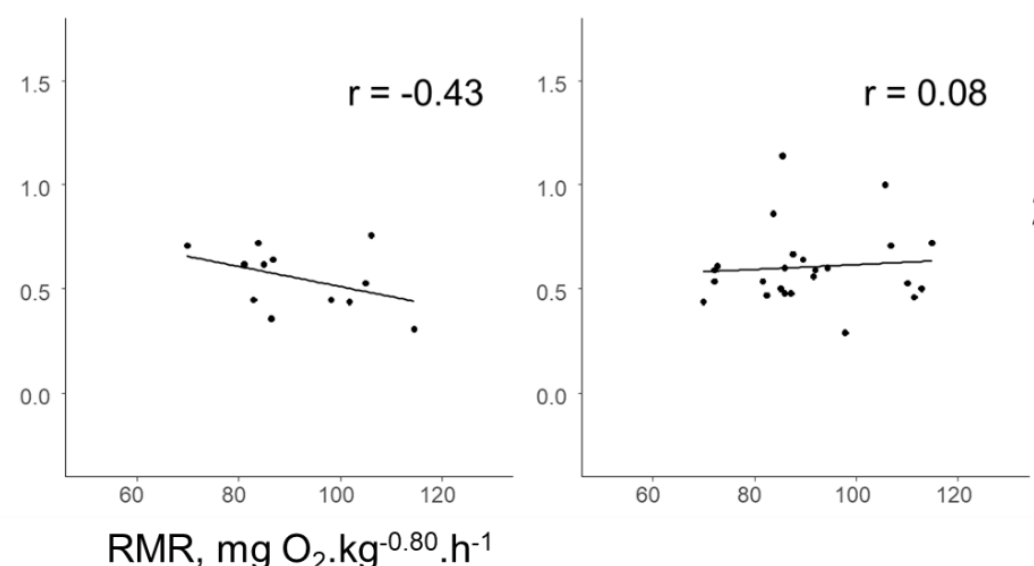

$24^{\circ} \mathrm{C}$

602

Fig. 4.

603 